\title{
Arabic Learning Model Development In Improving Reading Skill
}

\author{
Isop Syafe'I, Dadan F Ramdhan \\ UIN Sunan Gunung Djati Bandung, Indonesia \\ Isop.syafei@uinsgd.ac.id, dadanramdhan74@uinsgd.ac.id
}

\begin{abstract}
Arabic course is a university course that must be followed by all students of UIN Sunan Gunung Djati. Based on the observation, learning Arabic in UIN Sunan Gunung Djati Bandung reap the constraints and challenges in its implementation. To overcome this problem, the development of learning model can be considered as an alternative. This research uses research and development ( $R \& D$ ) method. Located on UIN Sunan Gunung Djati Bandung campus in Psychology course. Research subjects in this study were students and lecturers of Islamic Education Department Faculty of Tarbiyah and Teacher Training UIN Sunan Gunung Djati Bandung. In the implementation, this learning model is quite effective in order to improve the performance of lecturers and student motivation in the process of learning Arabic and is known to be more effective when compared with the Arabic learning that has been going on.
\end{abstract}

Keywords: Arabic Learning Model, Model Development, Reading Skill Improvement

\begin{abstract}
Abstrak
Mata kuliah bahasa Arab merupakan mata kuliah universitas yang wajib diikuti oleb selurub mahasiswa UIN Sunan Gunung Djati. Berdasarkan hasil observasi, pembelajaran bahasa Arab di UIN Sunan Gunung Djati Bandung menuai kendala dan tantangan dalam implementasinya. Untuk mengatasi hal ini, pengembangan model pembelajaran diduga dapat dijadikan salab satu alternatif. Penelitian ini menggunakan metode research and development ( $R \& D$ ). Berlokasi di kampus UIN Sunan Gunung Djati Bandung pada program studi Psikologi. Subjek penelitian dalam penelitian ini adalah mahasiswa dan dosen Jurusan Pendidikan Agama Islam Fakultas Tarbiyah dan Keguruan UIN Sunan Gunung Djati Bandung. Dalam pelaksanaannya, model pembelajaran ini cukup efektif dalam rangka meningkatkan kinerja dosen serta motivasi mahasiswa dalam proses pembelajaran bahasa Arab serta diketahui lebib efektif bila dibandingkan dengan pembelajaran bahasa Arab yang selama ini berlangsung.
\end{abstract}

Kata kunci: Model Pembelajaran Bahasa Arab, Pengembangan Model, Pengembangan Kemampuan Membaca

Permalink/DOI: http://dx.doi.org/10.18326/infsl3v12i2.283-305 


\section{Introduction}

Arabic course is a university course that must be followed by all students of UIN Sunan Gunung Djati. Its existence is very important in order to equip students in developing the competence that is being, because many science disciplines that use Arabic, let alone the development of science in UIN Sunan Gunung Djati Bandung who has the vision of revelation to integrate science with the frame of morality al-karimah which can be ascertained the source of many which uses Arabic. This course is a course directed to encourage, guide, develop, and nurture ability and foster positive attitude towards Arabic both receptive and productive. What is meant by receptive ability is the ability to understand other people's conversations and understand the reading, while the productive ability is the ability to use language as a means of communication both orally and in writing. (Cohen, 2014; Olshtain \& Murcia, 2017)

\section{Problems/Aims}

Based on the observation, learning Arabic in UIN Sunan Gunung Djati Bandung reap the obstacles and challenges in its implementation, including:

First, the student aspect (input). Among the obstacles and challenges in this aspect is the motivation to study Arabic among the less powerful students, the lack of basic skills of students in Arabic, and the basic ability of students in Arabic language is very varied, between one student with other students, making it difficult for lecturers to accommodate such abilities in the Arabic learning process.

Second, the competence of lecturers in learning Arabic requires the integrity between the competence of Arabic language with the competence of learning, whereas in fact, many lecturers of Arabic language have the competence of Arabic but have limitations in learning competence, or otherwise have competence in learning but have limitations in its Arabic competence. This is because generally their educational background is varied. The motivation of lecturers in applying their competence in learning Arabic less strong. 
This is generally due to their saturation in learning Arabic. Saturation is generally caused by facing various problems, constraints, and challenges in learning Arabic.

The curriculum development of Islamic Religion College is entirely submitted to the relevant universities, not including the curriculum of Arabic language courses at UIN Sunan Gunung Djati Bandung. Therefore, UIN Sunan Gunung Djati Bandung has full authority in formulating and implementing its curriculum. Arabic language learning has not improved the students' critical thinking skills, so they are not accustomed to thinking critically in the effort to read and understand Arabic scripts or books. The facilities and infrastructure in UIN Sunan Gunung Djati Bandung have limitations in the effort to realize optimal Arabic language learning.

Third, environmental aspects. Environment does not support students' Arabic language competence, so they are less likely to have an opportunity to study in an environment where they live (outside the campus) intensely.

To overcome this, development of the learning model is thought to be one of the alternatives. In the context of Arabic language learning in Arabic language and Arabic language majors, Arabic learning is directed in order to enable students to read/recite (maharat qira'at) and understand what is read (fahm maqru), so that they have the competence (tools) to develop their discipline. In order for students to have reading skills (mabarat qira'at) and understand what is read (fahm maqru), creative and innovative efforts are needed in learning. These efforts can be done by developing a learning model that can improve reading skills.

\section{Literature Review}

The linguist defines the language quite varied. Al-Khuli (1982: 148) says that language is a sound system consisting of arbitrary symbols used by a person or group of people to exchange ideas or share feelings. Meanwhile, Abdul Majid in Hermawan (2010: 5 - 15) argues that language is a collection of cues used by people to gather thoughts, feelings, emotions, and desires. Anis Farihah in 
Hermawan (2010: 5 - 15) suggests that language is psychological, social, cultural, non-biological, can be cultivated, composed of symbolic sounds that mean that one can communicate.

Furthermore, May Finachiaro in Hermawan (2010: 5 - 15) argues that language is an arbitrary system consisting of symbols of sound used by humans in transferring culture to others or those who have studied culture in communicating. Finally, Ronald Wardaugh in Hermawan (2010:5 - 15) understands language as an arbitrary speech symbol system used by humans to communicate. The diversity of this definition does not mean that language is as unclear. Precisely the diversity will further clarify the nature of language because of the diversity of reviews. Therefore, the essence of language may include; systematic, symbolic (composed of symbols), in the form of sound, arbitrary, unique, universal, varied, dynamic, communication device (Acep Hermawan, 2010: 8 -15).

\section{Previous Research}

Research conducted by Nazri Syakur, which is about communicative-kambiumi approach to learning Arabic. This research was conducted in order to complete the doctoral degree in the form of a dissertation at the State Islamic University (UIN) Sunan Kalijaga Jogjakarta in 2008. This research is based on the weaknesses in communicative approach. Of the various weaknesses found in this communicative approach, Nazri Syakur proposed several alternatives to perfect it. The intended communicativekambiumi approach is a learning model based on the psychology of cognitive learning, fully integrated through the all-in-one system, which will be able to develop all the elements of the communicative competence of the Arabic language which refers to psycho-linguistic feasibility. Implementation of learning is spread out in stages in each learning unit. Organizing material rests on reading and sound, followed by structured speaking and writing exercises, as well as grammatical learning. The methodology used in this research is qualitative study in the form of literature study, documentation, and reflection. The findings of his research are that the communicative approach requires several modifications, namely: (1) Learning other 
than needs-based as well as motivation (students will learn Arabic well if treated as individuals who need and are interested to master the Arabic language), the more skilled a learner develops learning motivation, learning Arabic will be more successful; (2) Prioritize the smoothness of communication also its accuracy; (3) Arabic use does not stop at contextual discourse alone, but also continues on discourse whose meaning is indirectly applicable in real life; (4) Student centered, that is; students are developed to be activeinteractive, creative, innovative, and reveal their psychologicalcognitive experiences. In addition, learning Arabic language should combine learning with two dialects, namely; the classical dialect for reading skills and modern dialect for skills express discourse/ sentence according to the context.

Research conducted by Asmawati Arif, which is about Arabic Learning Model with Multi Media Approach (Study of Arabic Learning at IAIN Imam Bonjol Padang). This research was conducted in order to complete the doctoral degree in the form of a dissertation at Universitas Pendidikan Indonesia in 2007. This research is based on the development of computer technology that is more advanced and can be applied in Arabic learning process. This research uses research and development (R \& D) method or research and development. One of the products that will be developed in this research is the learning model. Some of the findings in this study, namely; (1) the condition and situation of learning of Arabic at IAIN Imam Bonjol Padang which is running so far is considered less effective, (2) Development of learning model by using multimedia is a modification of computer based instruction (CBI) model with the aim to improve the quality of learning process, improve the effectiveness and efficiency of learning, facilitate active learning, orientate towards learners, and guide to study well, (3) Arabic learning model using multimedia is effective to improve lecturer's performance, and (4) Arabic learning using multimedia effective to improve student achievement.

Research conducted by Prof. Dr. Moh. Ainin, M. Pd., On Competence and Contextual Arabic Language Learning. This research was conducted in the framework of competitive research at State University of Malang in 2007. This research used qualitative 
design and classroom research. Subjects in this study were students of Field Experience Practice in State Junior Madrasah Aliyah even semester 2005/2006. The data in this study are qualitative data about the phenomenon of learning Arabic in the class conducted by the subject. Collection techniques are passive participation and interview observation. Key instruments are human instruments with auxiliary instruments in the form of observation guides, field notes, and interview guides. Data analysis approach used is interactive data analysis approach. The findings of this research are; assessment conducted by practitioner in learning Arabic is taken in two ways, namely the assessment of the learning takes place (classroom based learning) and assessment of results per Basic Competency.

\section{Theoretical Framework}

Atanotherpointofview, eachlanguagehasitsowncharacteristics that distinguish it from other languages. This characteristic as well as a power that even in certain cases is unparalleled. Similarly, Arabic has several characteristics that distinguish it from other languages. Uthman Amin (1965) in Acep Hermawan (2011: 58 - 71) describes these characteristics philosophically. This characteristic is seen as the superiority of Arabic over other languages in the world. According to the basic characteristics of Arabic can be seen in terms of; the subjectpredicate mental contact, individual presence, parallel rhetoric, i'rab existence, dynamics and power. In addition, Nayif Ma'ruf (1985: 4347) adds the importance of meaning, vocabulary richness, two-word integration, and analogy. Arabic is a language that has a unified whole and strong. Without intending to overpower the Arabs, for them utterances, thoughts, and deeds are complementary in life. The Arabian's instructor is his mind and his mind is the beginning of his actions. These three things become a power of language that can only be possessed by this language. Usually, the root of a word will give birth to many other words. This shows that Arabic is dynamic, but behind it is the power that shows that Arabic stands firm, not easily shaken. The dynamics and strength of the Arabic language is sustained by standards whose validity is accountable to the present day. That standard is no other Qur'an. It is amazing, the language of the Qur'an never lapsed in time, timeless, and never 
dying despite different places. Until now the language of the Qur'an remains a source of inspiration that is never exhausted from various facets and by various circles.

Furthermore, each of these skills is also closely related to the processes underlying the language. A person's language reflects his thoughts (Pennebaker \& Graybeal, 2001). The more skilled a person speaks, the brighter and clearer his or her way of thinking. Therefore, developing language skills can mean developing thinking skills. These skills are only cultivated and mastered by practice and a lot of practice. To see the progress of the practice and practice it is necessary to look at the components that make up the four skills. Herris (1977: 11) in Taringan (2008: 3) describes the components as shown in the following table.

\section{Table 1 Language Skills}

\begin{tabular}{|c|c|c|c|c|}
\hline \multirow{2}{*}{ Component } & \multicolumn{4}{|c|}{ Language Skills } \\
\hline & Listening & Speaking & Reading & Writing \\
\hline Phonology & $\sqrt{ }$ & $\sqrt{ }$ & - & $\cdot$ \\
\hline Orthography & - & - & $\sqrt{ }$ & $\sqrt{ }$ \\
\hline Structure & $\sqrt{ }$ & $\sqrt{ }$ & $\sqrt{ }$ & $\sqrt{ }$ \\
\hline Vocabulary & $\sqrt{ }$ & $\sqrt{ }$ & $\sqrt{ }$ & $\sqrt{ }$ \\
\hline $\begin{array}{c}\text { Speed/General } \\
\text { Proficiency. }\end{array}$ & $\sqrt{ }$ & $\sqrt{ }$ & $\sqrt{ }$ & $\sqrt{ }$ \\
\hline
\end{tabular}

Reading Skill (Maharah al Qira'ah/Reading Skills) is the ability to recognize and understand the contents of something written (written symbols) by pronouncing or menvernanya in the heart. Reading is essentially a process of communication between the reader and the author through the text he wrote, then directly in it there is a cognitive relationship between spoken language and written language. Taringan (2008/ III: 7) sees that reading is a process done and used by the reader to get a message that would be conveyed by the reader to get the message to be conveyed by the author through the media words/written language. Reading is thus an element that brings meaning, and a written symbol as a 
visual element. The transfer of written symbol into speech language is, according to Ibrahim (1962: 57), called reading.

In a broader sense, reading is not only glued to the activities of reciting and understanding the meaning of reading well, which involves only cognitive and psycho-motoric elements, but more than that concerns the inspiration of the content of the reading. So a good reader is a reader who is able to communicate intimately with the reading, he can be happy, angry, amazed, miss, sad, and so forth according to the reading wave. More broadly read not only that, but using the contents of that reading in everyday life. So a good reader is one who uses the content of the reading in his life (Ibrahim, 1962: 58). So reading in this last sense includes four things at once, namely; (1) to recognize written symbols, (2) to understand the meaning contained, (3) to address the meaning contained, (4) the implementation of meaning in everyday life. Reading in a very wide meaning is not easy, because many variables are involved, but for just the introduction, the ability to pronounce words and understand the full meaning is included. The importance and implementation meaning is life will emerge later with a lot of exercise.

The reading activity by Richards (1998: 238) is defined as perceiving a written text in order to understand its contents can be done silently, known by the name of silent reading and the result is called reading comprehension; can also be done by voice, known as oral reading and the result is not always an understanding. Types of reading comprehension are at least 4 (four), namely: (1) literal comprehension is done to understand all information explicitly written, (2) inferential comprehension is done to understand information that is not explicitly written by utilizing the experience and intuition of the reader, (3) critical or evaluative comprehension is used to compare information in a written text with the knowledge and values that the reader believes, and (4) appreciative comprehension is used to obtain the emotional values of a reading.

Rivers and Temperley (1978: 187-188), as quoted by Nunan (1989: 33-34), states that the purpose of a person reading a written text is at least one of a combination of 7 (seven) objective criteria; (1) to obtain information or curiosity on a number of topics, (2) to 
understand instructions, (3) to take part in drama, game or puzzle solving; (4) to connect with others by mail or understand business letters, (5) to know when and where something is happening or whether something is available or not, (6) to know what is happening or has happened (as is usually reported in magazines or newspapers), and (7) for fun.

Based on the essence of Arabic that has been described previously, Arabic has its own specifications and specifications that need special attention in the learning process. Learners not only learn the language, but also learn about the language. Thus, Arabic learning is not focused on the substance of language alone, but other issues related to language learning need to be taken seriously. In Arabic learning, can be directed to the meaning and function of the language itself. Language is not only seen as a means of oral and written communication, but also as an expression based on the rules, rules, and structures that apply to that language. Learning a language is learning about the rules, learning the structure and learning about the rules. Therefore, language learning needs to develop competencies that lead to language characteristics, meaning that the process of language learning is not only focused on student strategies in learning, the role of educators in teaching, and the methodology used in teaching, but also on the substance of the subject or characteristics, either viewed from the linguistic side, as well as from the cultural side attached to the language.

The main purpose of language learning is to help learners to be able to use target language both active-productive (speaking and writing) or passive receptive (listening and reading) (Djiwandoro, M. Soenardi, 1996: 60). To achieve this goal, a language educator must know and understand the principles of language learning that must be realized into the learning activities. Here are some principles of language learning and their methodological implications:

a. Learners will learn the language well if they are treated as individuals who have needs and interests.

b. Learners will learn well if he deliberately focuses his lessons on forms, skills, and strategies to support the process of obtaining language 
c. In learning Arabic at a certain level, educators should focus their learning in the form of language, such as vocabulary, grammar, skills, and strategy through a variety of personalized exercises. Exercises can be done through individual or group activities, both oral and written.

d. Learners will learn the language well when they are given the opportunity to participate in the use of target languages communicatively in various activities. To create this condition, educators should be able to encourage and enhance the active involvement of all learners in communication by using the target language through activities such as games, problem solving, information gap, and others. Of course the educator is like a model in the use of the language.

e. Learners will learn the language well if they are given the opportunity to organize their own learning.

f. Learners will learn well if they are given appropriate feedback regarding the progress of learning.

Of course there are many other principles in language learning that are often overlooked by educators in the process of language learning in the classroom or many among Arab educators have not understood. One of the impacts of lack of attention to these principles is to be wrong in determining in choosing materials, approaches, methods, and media, so that students ultimately no motivation to learn the language so that learning Arabic less interested students. One of the efforts in improving the quality of standard Arabic learning is by improving the quality of educators through improving their understanding of learning concepts, and improving language competence of educators.

\section{Improved Understanding of Language Learning}

The essence of language learning is how a person develops a new habit in himself, the habit can be formed when the drill is continuously (Brown, 2000; Gass, 2013). Therefore, in language learning is intended to help learners to be able to master the four 
skills of language (maharat istima', kalam kuni, qiro'ah and kitabah mahara), in addition, in language learning is always based on standard rules, such as the number of hours enough, the frequency of practice and the use of a lot, a relatively small class, and educators who master the language and learning.

\section{Increased Educator Language Competency}

Language competence is a person's ability to create and understand sentences, including sentences they have never heard before, including one's knowledge of what is really sentence and which are not sentences of a particular language (Henry Guntur Taringan 1990: 22). Language competence can be classified with different angles, if the competence is viewed from functional proficiency angle, then there are three components, namely:

1. Participative competence, is the ability to give an adequate respond to class assignments and its finishing procedures.

2. Interactional competence, is the ability to respond against the rules of class discourse and the rules of social discourse, interacting adequately with peers and adults when completing classroom tasks.

3. Academic competence, the skills in acquiring new skills, assimilating or understanding new information, and building new concepts (Henry Guntur Taringan 1990: 25).

In order for language learning to run well and in accordance with the expected, then an educator must have certain qualifications as a condition of professionalism, so as to improve the standard quality of learning Arabic language. Thus an educator must have functional competence, knowledge, and skills. To meet the expected competencies, the institutions preparing candidates for Arabic lighoiri natiqina biha should pay attention to the following aspects:

a. The Linguistic Aspect, which is referred to in this aspect is a study related to the linguistic sciences, especially in the study of Arabic language learning lighoiri natiqina biha.

b. Aspects of the Profession, to make a professional language educator, then an educator must be equipped with educational 
sciences (Basic Education, Educational Psychology, Sociology of Education, Learning Design, Learning Methods, Evaluation Learning, Classroom Action Research, and so forth).

c. Cultural Aspects, there is an inseparable linkage between language and culture, because language is a container of a culture. With language, one will be able to understand, recognize, and even transfer a culture. Therefore, a language educator must have knowledge of the language culture being taught.

d. Aspects of Personality and Social, because educators are a model for learners, then an educator must have a whole personality such as; religious, confident, strong personality, master of material and others (Dihyatun, 2003).

The above aspects are things that should be given to Arabic educators, so they become competent and professional educators in carrying out their duties.

\section{Methods}

This research uses research and development ( $R$ \& D) method. The use of this method is intended to develop a learning model. One of the products to be developed in this study is a learning model that can improve reading skills. Data collection techniques in research and development of this model are adapted to the needs based on the research steps, that is in the preliminary study phase, the initial survey is conducted through the development of questionnaire instruments for students and for lecturers, as well as instruments for class observation. In the development stage of the model developed instructional results (posttest) instruments, class observation, and model justification test. For the test of validation developed instrument of learning result measurement through pretest and posttest.

Located in the campus of UIN Sunan Gunung Djati Bandung on Psychology study program. Subjects in this research are students and lecturers of Islamic Religious Education Faculty of Tarbiyah Faculties and Teachers of UIN Sunan Gunung Djati Bandung. Students in question are students who follow and contract Arab 
courses, while the lecturers are lecturers who teach Arabic courses. In this study, the subject of the study was a total of 200 students, consisting of 40 class A students, 40 class B students, 40 class C students, 40 class D students, and 40 class E. However, subjects were grouped into groups Experiments are class A consisting of 40 people, while the Control Group is taken from 40 undergraduate students of Islamic Religious Education at the Islamic Religious School of Sukabumi. The number of lecturers to be the subject of this research are 8 lecturers in the Department of Islamic Education Faculty of Tarbiyah and Teaching UIN Sunan Gunung Djati Bandung.

\section{Finding And Discussion}

In this section will be discussed about; (1) preliminary study results, (2) model development, (3) model implementation, and (4) model effectiveness. In detail the explanation as follows:

\section{Preliminary Study Results}

a. Arabic Language Learning Purpose

Arabic is a language that Muslims must understand, because this language is the language used in al-qur'an and al-hadith which is the guideline for all Muslims. In addition, Arabic is the language used when Muslims worship good when they perform prayers, as well as in prayer. Therefore, learning Arabic for Muslims becomes a necessity.

In general, the aim of learning Arabic for Muslims is to enable Muslims to understand the source of Islamic teachings al-Quran and al-hadith, to understand the various sources of Islamic teachings in Arabic, and to apply it in everyday life. Therefore, Arabic is no longer the only Arabic language, but it becomes the language of the Muslims all over the world. In his study, the aim of Arabic learning is directed towards reading skills.

\section{b. Learning System}

Every nation in the world uses different languages between nations and nations. The difference in language indicates the difference in language structure. In Arabic the language structure is 
called Kawaid al Lughah. While the Arabic language is comprised of al binyah (sharaf), kawaid and tandzim (nabwu), and balaghah.

The Arabic language, both al binyah (sharaf), kawaid and tandzim (nabwu), as well as balaghah are integral to one another and can not be separated, because each sentence in Arabic is interconnected between al binyah (sharaf), swirly and tandzim (nabwu), and balaghah. Therefore, to achieve the competence of Arabic language skills, understanding the three kawaid became a necessity. Thus, the implications of the learning can be the miner of ila al amtsilah kamaid or minal amtsilah ila al kawaid. Both can be applied in Arabic learning, both at the basic, middle, and higher levels.

In addition, in the Arabic language learning process, many things can affect the learning process and outcomes, namely; input, instrumental, and environmental. Inputs are learners, instrumentalists are educators, curricula, strategies, media, and so forth, while environmental is environment, friends, and so on.

Thus, in order to achieve the intended goal, its implication, the Arabic language learning system should consider both aspects, namely; aspects of Arabian language itself and aspects of learning. Both aspects have implications for the developed learning model.

\section{c. Results Obtained by Students}

Arabic learning process conducted by lecturers and students should result in various changes, whether in knowledge, understanding, skills, values, or in attitude. The existence of these changes, one of which can be seen from their motivation to learn the Arabic held on campus. Because knowledge, understanding, values, and attitudes start from a strong motivation to learn Arabic.

Based on the answers of students distributed through questionnaires to students of the first semester of the Islamic Education Department as many as 80 students, obtained various answers as follows;

Students feel happy to study on campus, this is proved by their answer as many as 52 students (65\%) answer fun because they will get knowledge, 20 students (25\%) answered astonishment, because many friends, and 8 students (10\%) answered no fun, 
because there are too many tasks. Based on these answers hinted that generally students feel happy to study on the campus UIN Sunan Gunung Djati Bandung, this shows that their motivation to learn high, although there are a small number of students who answered not happy, and even then because of too many tasks.

In relation to the students' view of the learning process at UIN Sunan Gunung Djati Bandung, 56 students (70\%) answered gave a lot of knowledge and useful for their life and life, and 24 students (30\%) gave answers to make me know. Based on these answers hinted that generally students understand the function of learning, which can give them a lot of science and useful for life and life. This indicates that their learning goals are good.

However, when students were asked about which subjects were the most favored, they answered 24 students (30\%) answered more Indonesian, 36 students (45\%) answered English, and 20 students (25\%) gave more Arabic-like answers. Based on these answers indicate that among those who are interested in learning Arabic is very less, only 25\%. Therefore, it is expected for Arabic lecturers to increase their motivation to learn Arabic.

In addition, students were asked about the most unpopular subjects, 26 students (32.5\%) gave Indonesian answers for reasons difficult to understand, 19 students (23.75\%) gave English answers for reasons difficult to understand, and 35 students (43.75\%) gave Arabic answers with reason too much rote. This shows that Arabic is the most unpopular of students, therefore, it needs strong motivation.

Based on the data from the answers of the students above, in general they feel happy or have a strong motivation to study at campus UIN Sunan Gunung Djati Bandung, but in Arabic courses generally they are less interested to learn it. Therefore, in learning Arabic students need a strong motivation to learn Arabic.

\section{Model Development}

The learning model is a conceptual framework that delineates systematic procedures in organizing learning experiences to achieve specific learning goals, and serves as a guide for learning designers 
and educators in planning learning activities so as to provide a framework and direction for educators in the implementation of learning. Thus, the learning activity is truly a systematically organized objective activity. Through learning that emphasizes the reading skill, students are expected to be able to communicate by using the language they learn, either orally or in writing. This ability to communicate requires language skills which in turn will affect the ability to reason or think, and will also affect the ability to broaden the horizons.

\section{Model Implementation}

a. Lecturer's Role in Model Implementation

In essence, the lecturer plays an important role in the planning and implementation of the curriculum. This means that no matter how good the curriculum is, the outcome depends very much on what the lecturers do in the classroom. As a planner, lecturers must organize teaching materials to be operated. Teaching materials or learning content not only consists of a collection of information, but must be a unity of knowledge selected and needed both for the knowledge itself and for students so as to support the mastery of something competence. In the content planning or material done by the lecturer is the analysis of the subject matter to explore the concepts to be developed. Because the lecturer is the person who most understand about the ins and outs of learning, then in the hands of the lecture the learning theory is managed and implemented into the presentation of the material, to lay the pedagogical basis of the learning model. Therefore, in a class, lecturers play an active and responsible role in learning. Lecturers and students work together in partnership. The most important strategy that will realize the partnership is negotiation. Learning negotiations between lecturers and students tend to produce learning experiences that will accommodate students' needs, interests, and abilities. Lecturers and students work together in the direction and trust that comes from understanding the learning activities.

In the implementation of the developed model, prior to the training and analysis phase, the lecturer interacts with the students, 
the lecturer acts as a facilitator, such as saying greetings, greeting students, and asking questions to students both related to past material and materials to be studied in order preparing the learning process. In addition, when the lecturer explains the purpose of learning so that students know the targets to be achieved through the learning process, the lecturer acts as a communicator. Then in the effort to achieve the objectives that have been determined through the learning process, the lecturer acts as a facilitator when grouping students and submit written discourse (text reading) in accordance with the learning materials that have been prepared. In the training and analysis phase, the lecturer acts as communicator, facilitator, and counselor when doing various activities in the framework of the implementation of learning using the developed learning model.

\section{b. Student's Role in Model Implementation}

In the learning process developed in this study, students should have the following characteristics; (1) always wishes to interpret the speech correctly, (2) wishes that the language used is always communicative, (3) do not feel embarrassed if make mistakes in communicating, (4) always adjust the form and meaning in communicating, (5) speak more highly, and (6) always monitor their own speech and speech utterances to see if the language patterns used are acceptable and understandable to the public. Based on these characteristics, the role of students in the implementation of learning models developed in this study are; first, as a negotiator between himself, the lecturer, the learning process, and the object of learning. Secondly, as an interactor. In this case, students are asked to interact primarily with other fellow students and interact with the lecturers. Third, as a giver and receiver. Referred to as the giver and recipient in the implementation of the Arabic learning model developed in this study is that when the learning process takes place, in addition to the students acting as recipients of learning given lecturers, they also play a role mutual giving with other fellow students in the interaction of learning.

The roles of the students, both as negotiators, interactors, and as givers and recipients, are manifested in the implementation of the 
Arabic learning model with the communicative approach developed in this study, both at the training stage and in the analysis phase.

\section{c. The Role of Material in Model Implementation}

In the learning model developed in this study, learning materials have a major role in the implementation of learning models. There are three types of learning materials that are widely used in language learning, namely; (1) textual material, (2) task-based material, and (3) materials based on authentic materials. Referring to the three forms of learning materials, then there are some principles of Arabic learning materials developed in this study, namely; (a) learning materials must support the objectives formulated in the curriculum, (b) instructional materials that are arranged in terms of necessity and authentic, (c) learning materials should be able to stimulate interaction between lecturers and students and interaction among students, (d) the learning materials presented should give students the opportunity to be able to pay attention to Arabic forms, (e) learning materials should be able to encourage students to develop reading skills, and (f) learning materials should be able to create students applying reading skills.

\section{d. Model Trial}

\section{1) Learning Model Design}

The design of learning model developed in this research, developed through the components, namely; objectives, materials, procedures, and evaluation of learning outcomes. Objectives to be achieved through the implementation of the learning model of development results is directed at improving students' reading skills. Thus, goal development refers to improving the reading skill.

Components of the material developed through the topics covered in the curriculum of Arabic semester 1 majoring in Islamic Religious Education Tarbiyah Faculty and Teacher Training UIN Sunan Gunung Djati Bandung. The material is adapted from Arabic (qawaid) rules as well as reading texts in order to improve the reading 
skill. In addition, Arabic learning materials refer to the expected competencies, namely; understand the rules of the Arabic language and its application. Therefore, Arabic learning materials include written discourse and rules (qawaid), Arabic language consists of morphology (qawaid al binyah/sorof science) and syntax (qawaid al tandim/ nabwu science). While the application is directed at reading skills. The components of the procedure are developed through the learning steps, namely; the first step is the exercise, and the second step is the analysis. While the evaluation component developed in the form of assessment instruments conducted by self, colleagues, and by lecturers. In the implementation, the Arabic learning procedure developed in this research includes 2 (two) steps, namely; exercise and analysis. Before the two steps are implemented, students are first given an explanation of the purpose of learning, given the motivation, grouped, and given written discourse.

In the analysis phase, the reading skill that is the focus of the exercise is used as the focus of analysis. In the analysis phase of reading skills, focused on how to read good and right. In the qawaid analysis phase, it focuses on the rules of learning materials and kawaid as a whole. While in the phase of relevance analysis between the objectives of learning and its implementation, more directed on the relationship between learning objectives with the substance of learning materials. After that, at the end of the lesson, the lecturer is required to conduct the learning evaluation through the learning result test developed in the form of self-assessment instruments, peers, and lecturers. Thus, overall it appears that the Arabic learning model developed in this study is designed with the aim that students have the skills to read. Reading skills (maharab al qira'ah), directed when lecturers invite the students to examine and read the text of the readings and then welcome to rewrite the substance of the reading in their own language. Based on these steps, it appears that reading skills are directed in a learning process.

2) Improved Learning Outcomes of Student Arabic Language

The results of experimental model of development that is carried out shows that there is an increase of evaluation result of 
learning result, completion of questions given and spirit of student study towards Arabic language course. Increasing the value of learning results can be seen from the test results 1 (one). The average score of learning outcomes obtained by the students is 64,9 with standard deviation 2,685 and trial 2 (two) increased to 71,7 with deviation standard 3,831, whereas in experiment 3 (three) average 84.7 with a standard deviation of 4,029. Thus, it can be said that the experimental model tested has provided an increase in the acquisition of student learning outcomes.

Students are very enthusiastic in following the learning of Arabic language in order to improve reading skill developed in this research, because they feel there is new innovation in Arabic learning process like model which researcher develop this.

3) Student Learning Activities Improvement

Implementation of the Arabic learning model developed in this study, has a positive impact on student learning activities. Students are very eager to follow the learning with the developed learning model. In solving the problems seen the improvement and improvement of the answers. When viewed from the test 1 the answers given not yet perfect, then at the test phase 3 students began to show a perfect answer in accordance with the expected answer. This shows that the improvement of the learning model gives the result as expected. The students' reading skill competence is expected to be used for the relevant courses.

4. Model Effectiveness

To see the effectiveness of the implementation of learning model in order to improve reading skill, conducted by validation test. The effectiveness of a learning model can be reviewed by way of implementation in the learning activities and measured based on the achievement of student learning outcomes treated compared to student learning outcomes that are not given treatment. It should be emphasized here that the results of study are the results of learning after students are given treatment.

The learning model developed in this study proved to be effective for improving the quality of Arabic learning. 
Before the learning model is implemented, development of learning planning is done. Among the objectives of learning planning is to analyze problems, design problem solving, implement and evaluate learning resources as a component of the learning system. The impact of the development of this plan is for lecturers to study the curriculum as a whole and expand the imagination to develop the learning materials. The next impact is the effectiveness of time, the learning process is more concentrated, the learning activities more lively, facilitate lecturers and students in the learning process, and in one learning process can include efforts to increase student competence in reading skills.

\section{Conclusion}

To see the effectiveness of the implementation of learning model in order to improve reading skill, conducted by validation test. The effectiveness of a learning model can be reviewed by way of implementation in the learning activities and measured based on the achievement of student learning outcomes treated compared to student learning outcomes that are not given treatment. It should be emphasized here that the results of study are the results of learning after students are given treatment.

The learning model developed in this study proved to be effective for improving the quality of Arabic learning.

Before the learning model is implemented, learning planning development was done. Among the objectives of learning planning is to analyze problems, design problem solving, implement and evaluate learning resources as a component of the learning system. The impact of the development of this plan is for lecturers to study the curriculum as a whole and expand the imagination to develop the learning materials. The next impact is the effectiveness of time, the learning process is more concentrated, the learning activities more lively, facilitate lecturers and students in the learning process, and in one learning process can include efforts to increase student competence in reading skills. 


\section{Reference}

Al-Khuli, Muhammad Ali. (1982). Asalib Tadris al-Lughab alArabiyyah. Riyadh: al-Mamlakah al-Arabiyyah al-Su'udiyyah.

Arif, Asmawati. (2007). Model Pembelajaran Bahasa Arab dengan Pendekatan Multimedia (Studi Pembelajaran Bahasa Arab IAIN Imam Bonjol Padang). Bandung: Disertasi UPI Bandung.

Brown, H. Douglas. (2000). Principles of Language Learning and Teaching. White Plains, MY: Pearson Education.

Cohen, Andrew D. (2014) Strategies in Learning and Using a Second language $2^{\text {nd }}$ Edition. London and New York: Routledge Longman Applied Linguistics

Dihyatun. (2003). Nabwa Istrartijiyai Ta'limul Lughob Al-Arabiyah Al-Fa'aliyah. Malang: Makalah Kuliah Tamu 16 Maret 2003 UIN Malang.

Djiwandoro, M. Soenardi. (1996) Tes Bahasa dalam Pengajaran. Bandung: Institut Teknologi Bandung.

Gass, Susan M. (2013). Second language Acquisition: An Introductory Course $4^{\text {th }}$ Edition. New York: Routledge.

Guntur Taringan, H. (2008). Berbicara sebagai Suatu Keterampilan Berbahasa. Bandung: Angkasa.

Guntur Taringan, H. (2008). Membaca sebagai Suatu Keterampilan Berbahasa. Bandung: Angkasa.

Guntur Taringan, H. (2008). Menulis sebagai Suatu Keterampilan Berbahasa. Bandung: Angkasa.

Guntur Taringan, H. (2008). Menyimak sebagai Suatu Keterampilan Berbahasa. Bandung: Angkasa.

Hermawan, Acep. (2010). Metodologi Pembelajaran Bahasa Arab sebagai Bahasa Asing. Bandung: Rosdakarya

Ibrahim, Abdul Alim. (1962). Al-Muwajjih al-Fanni li Mudarrisi alLughab al-Arabiyyah. Mishr: Dar al-Ma'arif.

Ma'ruf, Nayif Mahmud. (1985). Khasha'ish al-Lughah al-Arabiyyah wa Thara iq Tadrisiha. Beirut: Dar al-Nafa' is. 
Moh. Ainin. (2007). Pembelajaran Bahasa Arab Berbasis Kompetensi dan Kontekstual. Malang: Penelitian Kompetitif Universitas Negeri Malang.

Nunan, David. (1989). Designing Task for the Communicative Classroom. New York: Cambridge University Press.

Olshtain, Elite. \& Celce-Murcia, Marianne. (2017). Teaching Language Skills from a Discourse Perspective. Handbook of Research in Second Language Teaching and Learning, Volume 3 pp. 144 $-158$.

Pennebaker, James W. \& Graybeal, Anna. (2001). Patterns of Natural Language Use: Disclosure, Personality, and Social Integration. Sage Journals of Current Directions in Psychological Science Volume 10(3) pp. 90-93.

Richard I. Arends. (1998). Learning to Teach. Boston: The McGrawHill Companies.

Syakur, Nazri. (2008). Model Pembelajaran Bahasa Arab dengan Pendekatan Komunikatif. Jogjakarta: Disertasi UIN Jogjakarta. 